\title{
THE EVOLUTION OF EUROPEAN BUSINESS ENVIRONMENT IN THE LAST FOUR YEARS
}

\author{
Marcela-Cornelia Danu \\ "Vasile Alecsandri” University of Bacău \\ marceladanu@ub.ro
}

\begin{abstract}
In the present work I described the evolution of the main coordinates of the business environment in the countries of Europe. I examined the dynamics of economic growth, inflation, budget balance, current account balance, public debt for 41 European countries, taking into account their delimitation of regional groups. Analysis of the business environment in the countries of Europe using the indicators "assessment of the business climate" and "country risk" is aimed at identifying signals which are transmitted by the national economies, to the system of European economy, to the system of global economy but, in particular, the application optimal policies for improving the quality of the societal environment on the continent. I analyzed the impact of economic growth and inflation on business development, establishing relations between the rate of economic growth - the dynamics of the number of enterprises, the rate of inflation - the dynamics of the number of enterprises from 19 countries in Europe.
\end{abstract}

\section{Keywords}

economic growth; inflation; budget balance; current account balance; public debt; country risk; business climate

\section{JEL Classification}

O10; O11; O52; E01; E66

\section{Coordinates of the business environment in Eastern Europe}

After the economic and financial contemporary crisis, evolution of the European economy as a whole, has been breeding in the sinewave - 2010 and 2011, decrease in 2012, with the relative stabilization in 2013 (http://epp.eurostat.ec.europa.eu/ statistics_explained). Socio-political context and economic situation of each country on the European continent, the magnitude of the economic downturn and its effects on regional institutional framework to which they relate, etc., European economies have led to different situations in life, economic dynamics specific to each State entity.

In terms of growth of gross domestic product in the period 2011-2014* (estimate 2014) at the level of 10 Eastern European countries (www.un.org/) (Fig.1), if in the year 2011 the largest GDP increases were registered in the Republic of Moldova (www.coface.com/) (6.8\%), Belarus (5.5\%) and Ukraine (5.2\%), in 2012, the recession year at the level of the whole continent, the Russian Federation has registered the highest economic growth in the region (3.5\%); the Republic of Moldova, The Czech Republic and Hungary have had negative economic growth; in 2013 was a revival for the Republic of Moldova, Poland, Romania, Hungary and a decrease, compared to the previous year, the economic growth in Bulgaria, Russia, Slovakia, Ukraine; 2014 bring the resumption of economic growth in most of the countries of Eastern Europe.

The evolution of inflation in the region under analysis (Fig.2) shows large discrepancies, from levels of more than 50\% in 2011 and 2012 in Belarus and to less 
than 5\%, during the time, in Bulgaria, Poland, the Czech Republic, Slovakia; on the same background of the discrepancies is the Belarusian situation which, from a level of $59.2 \%$ in 2012 has descended to a level of 17.5\% in 2013, reaching $14.8 \%$ in 2014 (estimate).

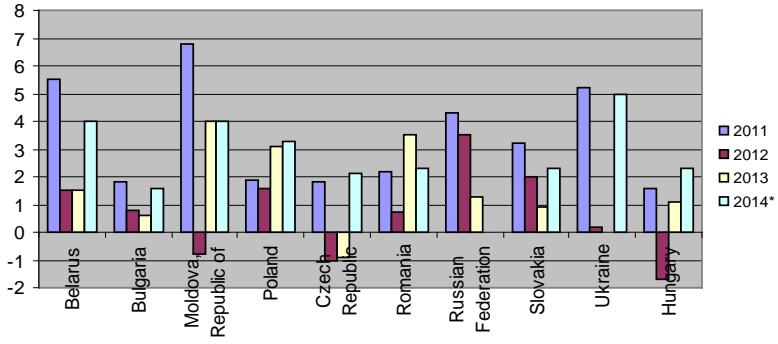

Fig.1.GDP growth (\%) in East Europe

Source: Processed by www.coface.com

None of the countries of this region has not recorded a continuous decreasing trend of the rate of inflation but also favourable macro-economic situations have been Bulgaria, Poland and the Czech Republic, Slovakia, Romania, Hungary. Having determination the region's geopolitical situation, Ukraine has evolved positively in the period 2012-2013, the rate of inflation dropping from 8\% in 2011 to $0.6 \%$ in 2012 and even the deflation $(-0.3 \%)$ in the year 2013, reaching once again into the 2014 level in 2011 (8\%) estimate. Belarus, Russia, Ukraine and the Republic of Moldova shall be maintained with high levels of inflation in 2014.

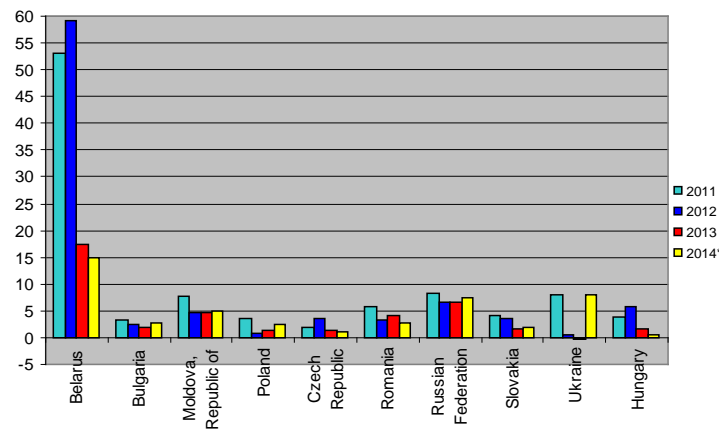

Fig.2. Inflation (yearly average) (\%) in East Europe Source: Processed by www.coface.com

Another dimension of evaluation of the quality of the business environment is the budget balance (Fig. 3). In all the analysed the situation in this region reflects the high levels of budget deficit to GDP. The most difficult cases are in Ukraine, where the budget deficit of $-2.8 \%$ of GDP in 2011, it was stressed at $-4.3 \%$ in $2012,-4.8 \%$ in 2012 and $-5.2 \%$ in 2014 (estimate). A descending trend of Hungary which had, from a budget surplus of $4.2 \%$ in 2011 fell continuously, reaching $-2.9 \%$ of GDP budget deficit, estimated for the year 2014. Excessive deficit situations with high levels were recorded in this period, in Slovakia too $(-5.1 \%$ in $2011,-4.3 \%$ in $2012,-3 \%$ in 2013, $4 \%$ in 2014). Significant is the dynamic of budget balance in Belarus which, starting from a budget surplus of $2.8 \%$ in 2011 fell to $0.7 \%$ in 2012 and $0.2 \%$ in 2013, for 
2014 is estimating a budget deficit of $-0.7 \%$ of GDP. The current account balance illustrates, for the countries of Eastern Europe, difficult situations and negative developments for Moldavia, Ukraine and Belarus in the last 4 years. In the Republic of Moldova the deficit of the current account was $-11.3 \%$ of the GDP in 2011, $-9.4 \%$ in 2012, $-10 \%$ in 2013, expected a level of $-9.7 \%$ in 2014.
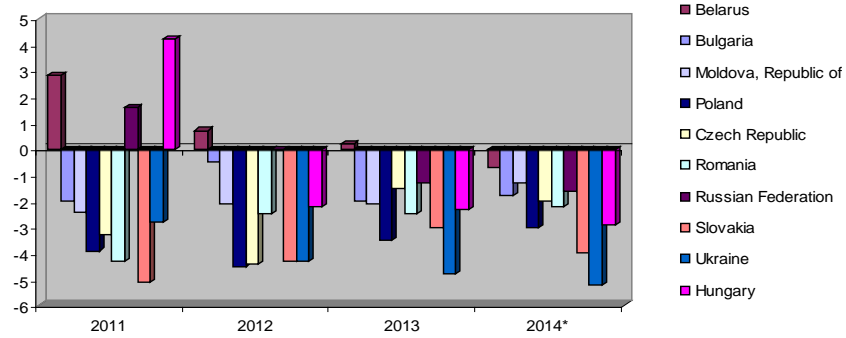

Fig.3. Budget balance (\% GDP) in East Europe

Source: Processed by www.coface.com

Bulgaria, Slovakia and Hungary have registered a good evolution of balance of current account but Czech Republic, Poland and Romania (from $-4.5 \%$ of GDP in 2011, to $-4.4 \%$ in 2012 and $-1.1 \%$ 2013, estimating a growth to $-1.3 \%$ in 2014 . The countries in the region with a surplus current account during the last 4 years are Russian Federation and Hungary.

In the case of public debt, in most of the countries of region, the level has decreased in 2014 as compared with the previous years. However, in Hungary the public debt, as a percentage of GDP, has remained high in all these years (80 \%, $79 \%, 79 \%, 81 \%$ ). At the opposite pole is placed Russian Federation with the lowest levels of public debt (9.8 \%, $11.8 \%, 10.8 \%, 11.6 \%)$ and Bulgaria too.

\section{Dimensions of the business environment in Northern Europe}

In Northern European countries in 2011, economic growth (Fig.4) recorded the highest levels in the Baltic States (Estonia 9.6\%); in 2012, with the exception of Norway and Latvia which have recorded a positive dynamic of economic growth, all other countries have regressed and Finland, Denmark and Ireland have had negative economic growth; in 2013, as compared to the previous year, increased Denmark, Iceland, United Kingdom, Ireland and Sweden, and Finland was left alone in the region with negative economic growth; in 2014 the most of the Northern European countries had higher levels of economic growth compared to the previous year.

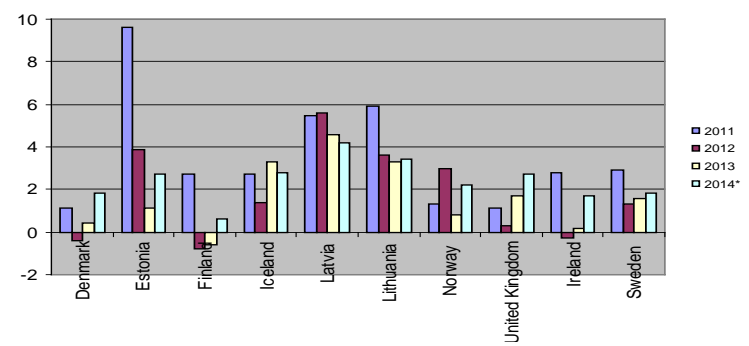

Fig.4.GDP growth (\%) in North Europe Source: Processed by www.coface.com 
In Northern Europe, inflation (Fig.5) has not represented a special problem during the last four years, although in that region are developed countries, members of the European Union, developed countries not members of EU and ex-communist countries, membres of the EU, each of them bearing the imprint of the history and development of the economic policies implemented over time. The majority of the countries in this region have seen favorable developments of the level of inflation, so, for 2014 are estimated inflation rates of less than 4\%; the dynamics of inflation has followed a decreasing trend in the majority of cases, in all four years of study.

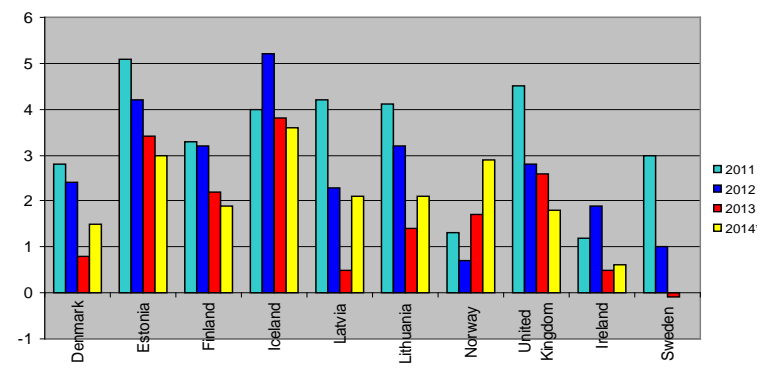

Fig.5. Inflation (yearly average) (\%) in North Europe Source: Processed by www.coface.com

As regards the situation budget balance (Fig.6), in the region, in the year 2011, Ireland and the United Kingdom were faced with the highest levels of budget deficit (Ireland recording the largest budget deficit at the level of Europe), is maintained in the last four years but the trend of revival in the case of Ireland $(-13.1 \% ;-8.2 \% ;-7.2$ $\% ;-4.8 \%)$. Norway is the only country in the region with a surplus budget and Sweden, starting from a situation of budget balance in the year 2011, the regressed gradually, reaching the budget deficit of $-1.4 \%$ of the GDP in the year 2014 (estimate). On the whole, in the year 2014, the budget deficit, as well as weighted in the GDP, has been kept relatively in the same intervals of variation as well as in the year 2013, dynamic being positive as compared with the year 2011.

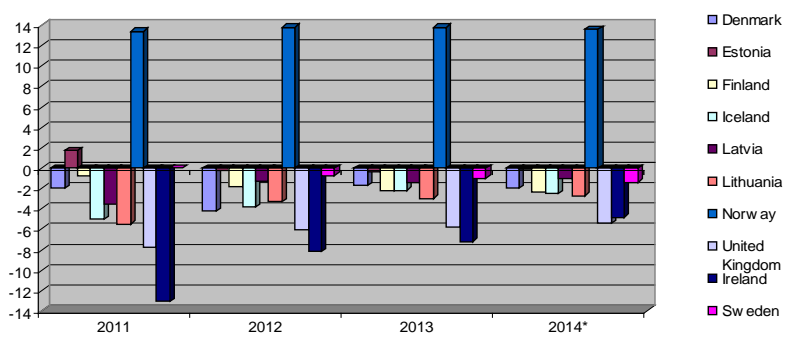

Fig.6. Budget balance (\% GDP) in North Europe

Source: Processed by www.coface.com

In Northern Europe, the current account balance in 2011, was in surplus in the case of Norway (12.8\% of GDP), Sweden, Denmark, Estonia, and Ireland and in deficit in case of the other five countries in the region (Iceland,-6.3\% of GDP). It is significant positive developments in Iceland which decreased the current account deficit up to $2.9 \%$ of GDP in 2014 (estimate), Latvia (from -2.1\% of GDP in 2011, to $-1.3 \%$ of 
GDP in 2014) and Lithuania (from -3.7\% in 2011, to -1.2\% in 2014). Also, is notable the increase in the current account surplus of Ireland (from 1.2\% in 2011 to $6.9 \%$ in 2014).

As regards public debt, some of the northern European countries are faced with high levels of it. The situation has, however, different, from one country to another, thus, if in the year 2011, Estonia had a debt of 6.1\% of GDP, Ireland had a debt of $104.1 \%$ of GDP, Iceland had a debt of $102.3 \%$ of GDP and UK $84.3 \%$ of the GDP. In the 2014, only Iceland, Latvia and Norway were weightings of public debt in GDP smaller than in the 2011; all other 7 countries of the region have emphasized dependence on public sector by the private sector national or international. Worrying has become increase of the share of public debt in the GDP in the case of Ireland to $120.7 \%$ but also in the case of the United Kingdom to $92.5 \%$.

\section{Evolution of the business environment in South-Eastern Europe and Transcontinental}

In the South-Eastern and Transcontinental (Turkey) changes in economic growth (Fig.7) reflects the difficulties that have faced or are facing, yet, the countries of the region. If, in year 2011 the Turkey has recorded an increase in GDP of 8.8\% and Albania, Macedonia and Montenegro have recorded GDP increases of over 2\%, in the year 2012 all the countries of southern Europe and Turkey also had decreases in the levels of economic growth from 2011; with the exception of Albania, Malta and Turkey, all others have had negative economic growth. The situation has not improved than in Bosnia and Herzegovina, Macedonia, Malta, Montenegro, Serbia and Turkey, continuing in the year 2014 too, only in Macedonia, Malta and Montenegro. It is significant that some countries have been in economic recession in 2012 and 2013, were revived in the year 2014; the case of Greece, Italy, Portugal, Slovenia and Spain. Other - Cyprus and Croatia, in the same way as those referred to above states of EU, have not been able to get out of the cone of negative economic growth nor in the year 2014 .

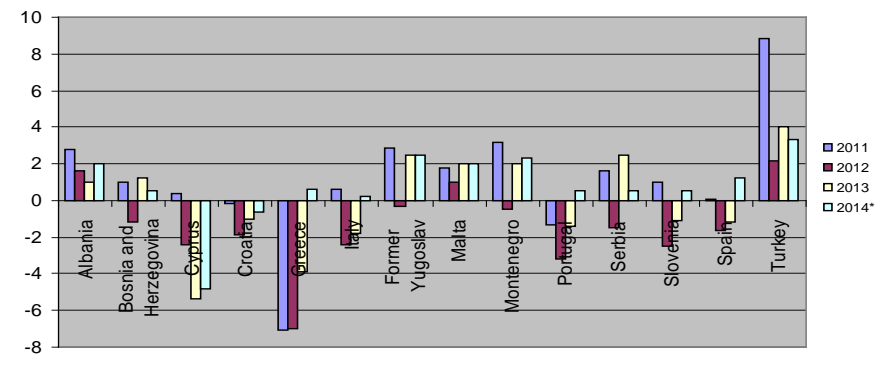

Fig.7.GDP growth (\%) in South Europe and Transcontinental Source: Processed by www.coface.com

In the period under consideration, in South-Eastern Europe and transcontinental, inflation was, in majority, moderate (Fig.8), except for Serbia and Turkey which have exceeded the threshold inflation rate of $5 \%$. 


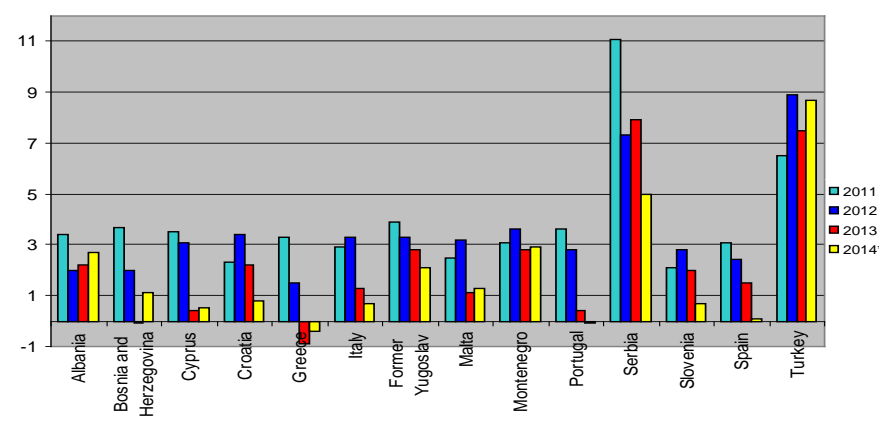

Fig.8. Inflation (yearly average) (\%) in South Europe and Transcontinental Source: Processed by www.coface.com

It is significant that Serbia has evolved positive, thereby reducing the level of inflation from $11.1 \%$ in 2011, to 5\% in 2014 but Turkey has evolved negative, increasing the level of inflation at $6.5 \%$ in 2011 to $8.7 \%$ in 2014 (estimate). It is notable that, in the majority, the level of inflation in 2011 was diminished until 2014. Greece, Bosnia and Herzegovina and Portugal have recorded cases of deflation (Greece in the years 2013 and 2014, respectively $-0.9 \%$ and $-0.4 \%$, Portugal, in 2014, $-0.1 \%$, Bosnia and Herzegovina, in 2013, $-0.1 \%$ ).

Budget balance situation shows that all the countries of the region have the budget deficit for the past 4 years (Fig.9). If in 2011, Greece and Spain had the highest levels of the budget deficit (both, $-9.6 \%$ of GDP) in 2014 Greece reached a budgetary deficit of $-2.7 \%$ of GDP and Spain at $-5.6 \%$ of GDP. In the opposite direction have evolved Albania, which on a budget deficit of $-3.5 \%$ in the year 2011, reached a deficit of $6,5 \%$ in the year 2014 , Serbia, from $-4,3 \%$ of the GDP, to $-8.5 \%$ of the GDP.
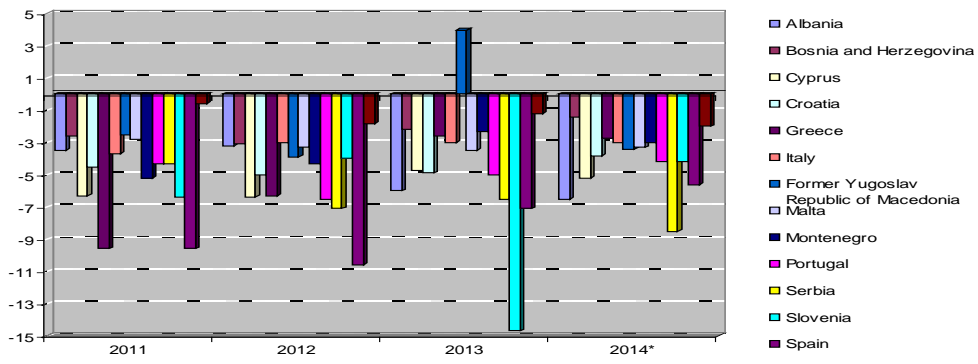

Fig.9. Budget balance (\% GDP) in South Europe and Transcontinental Europe Source: Processed by www.coface.com

As regards current account balance, in the year 2011, the current account deficit of more than $-9 \%$ shall be recorded in Montenegro (-17.7 \%), Albania (-12 \%), Bosnia and Herzegovina, Greece, Turkey, Serbia. With the exception of Montenegro that has diminished slightly the deficit in the four years, reaching, according to estimates at $16.2 \%$ in 2014 , in all other countries the situation had improved, reaching Greece, in 2014, to a surplus of $0.9 \%$ of GDP. In 2014, the balance of the current account surplus was in Slovenia, Italy, Croatia, Cyprus, Greece, Spain, Portugal.

In 2011, the public debt do not raise special problems in non EU countries. Has reached high levels in Greece (170.3\% of GDP), Italy (120.7\% of GDP), Portugal (108.2 percent), Cyprus, Spain, Malta. Excepting of Turkey, in all 14 countries of the 
Southern Europe and Transcontinental, public debt has risen over the last 4 years; in Cyprus increased by $70.88 \%$ (2014 from 2011), in Slovenia increased by $69.85 \%$ in Croatia, Spain, Serbia - has increased by over $40 \%$.

\section{Short radiography of the business environment in Western Europe}

In the same way as in the case of Northern Europe, in this region, all countries, member or non-member states of EU., are developed countries and, more than that, none of these is not part of the group of ex-communist countries.

Amid economic development and especially, as a result of smart economic policies recovery, the economic crisis has not left deep and lasting footprints in societal life. If in 2011, all the countries in the region recorded positive economic growth (Fig.10) Germany and Austria, with the highest values (3.3\% and 2.8\%) in the year 2012 the decrease was generalized, and in the case of the Netherlands, Luxembourg and Belgium, the economic growth became negative (-1.6\% in Netherlands). In the year 2013, Luxembourg has exited the recession increasing, from $-0.2 \%$ in 2012 to $1.9 \%$, while maintaining in 2014 too; Switzerland has been on a rising trend that has maintained in 2014. Compared with 2013, in 2014, excepting of Luxembourg, all other countries in Western Europe have registered an increase in economic growth.

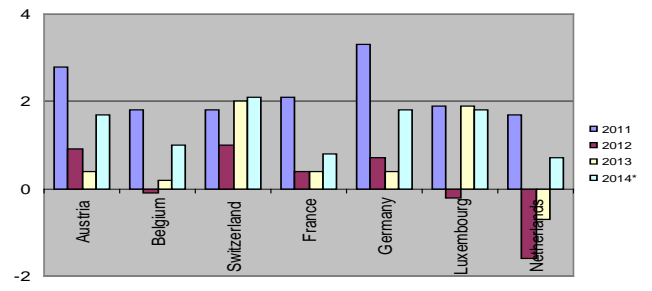

Fig.10. GDP growth (\%) in West Europe

Source: Processed by www.coface.com

In the period 2011-2014, the rate of inflation in Western Europe (Fig.11) was less than 5\%. In 2011, Luxembourg had a rate of inflation of 3.7\%, while Switzerland by $0.2 \%$. In 2012, all the countries of Western Europe have diminished the level of inflation, excepting of the Netherlands, which registered an increase from $2.5 \%$ in 2011, to $2.8 \%$ in 2012. In this year, Switzerland registered deflation, a situation that has kept it in 2013. In 2013, the rate of inflation fell again, in 7 countries of the region, 6 of them with a "quiet" inflation and only moderate inflation - Netherlands (2.6\%). Although in the year 2014 it is estimated slight increases in levels of inflation in the countries of Western Europe (Germany, from 0.4\% in 2013, to 1.8\% in 2014), none of the countries does not exceed the level of the "quiet" inflation, creating favourable conditions for societal development.

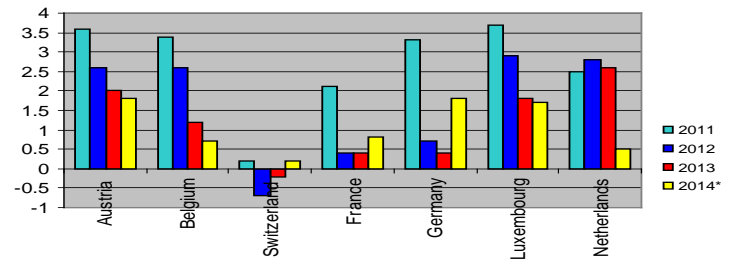

Fig.11. Inflation (yearly average) (\%) in West Europe Source: Processed by www.coface.com 
Either as regards budget balance (Fig.12), have not been particular problems, in the last four years, in this region. In 2011, France (-5.1\% of GDP) and the Netherlands ($4.3 \%$ of GDP) have recorded the highest levels of budget deficit, while, Switzerland and Luxembourg have had budget surpluses. In 2012, in Belgium increased budget deficit and Luxembourg has passed, from the surplus to the budget deficit, maintaining the situation up to the year 2014. Year 2014 has meant a deterioration in the budget balance for Austria; Switzerland has had budget deficit, in the Netherlands and Luxembourg has increased the deficit. This year, Germany exceeds the budget deficit situation, passing the budget surplus.

The current account balance shows, in 2011, the deficit in the case of France and Belgium, the situation that these countries it perpetuates in all these last years, but the proportion in the GDP deficit decreases only in the case of France (from $-1.8 \%$ of GDP in 2011, to $-1.1 \%$ of GDP in 2014). Other countries have current account surpluses, most of Switzerland (which increases the operating surplus at 8.9\% of GDP in 2011, to $13.9 \%$ of GDP in 2014), the Netherlands (8.7\% of GDP in 2014), Germany (7.2\% of GDP in 2014).

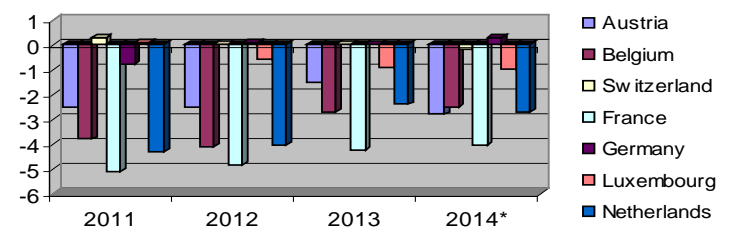

Fig.12. Budget balance (\% GDP) in West Europe

Source: Processed by www.coface.com

The level of public debt, it is, on the whole, maintained, during the 2011-2014. Austria, Belgium, France, Luxembourg and the Netherlands have increased the share of public debt to GDP while Germany and Austria have lessened it (most of Germany, from $80 \%$ GDP, to 75.7\% of GDP). So in 2011 and 2014, the lowest levels of public debt to GDP were in Luxembourg.

\section{Evaluation of the European business environment, 2011-2014}

Assessment of business environment according to COFACE is done with the help of two cumulative where appropriate indicators: business climate and country risk. The analyses use a seven-level ranking: in ascending order of risk, these are: A1, A2, A3, A4, B, C and D. Regarding to an assessment of the business climate and the country risk in the Eastern Europe, in the year 2014, we notice that none of countries has not reached the level of A1; Czech Republic, Slovakia and Hungary are valued with the index A2 and Belarus, The Republic of Moldova and Ukraine are rated the most weak. The situation is as significantly different as regards country risk assessment, in this case, only Poland reaching A2; the highest level of country risk is in Belarus and the Ukraine; generally, in the region of eastern Europe both the quality of the business climate and the country risk indicates a situation with a high potential for improvement, however, highlighting a modest credibility of the business environment. 
Table 1. Assessment of the business climate and country risk in Europe, 2014

\begin{tabular}{|c|c|c|c|c|c|c|c|c|c|c|c|c|c|c|}
\hline $\begin{array}{c}\text { Eastern } \\
\text { Europe } \\
\text { Indicators }\end{array}$ & BY & \multicolumn{2}{|c|}{ BG } & MD & PL & \multicolumn{2}{|c|}{$\mathbf{C Z}$} & RO & \multicolumn{2}{|c|}{$\mathbf{R U}$} & SK & \multicolumn{2}{|c|}{ UA } & HU \\
\hline $\begin{array}{c}\text { Business } \\
\text { climate }\end{array}$ & D & \multicolumn{2}{|c|}{ B } & $\mathrm{D}$ & A3 & \multicolumn{2}{|r|}{ A2 } & A4 & \multicolumn{2}{|c|}{ B } & A2 & \multicolumn{2}{|l|}{$\mathrm{D}$} & A2 \\
\hline $\begin{array}{c}\text { Country } \\
\text { risk }\end{array}$ & $\mathrm{D}$ & \multicolumn{2}{|c|}{ A4 } & C & A2 & \multicolumn{2}{|r|}{ A4 } & B & \multicolumn{2}{|c|}{ C } & A3 & \multicolumn{2}{|l|}{$\mathrm{D}$} & B \\
\hline $\begin{array}{c}\text { North } \\
\text { Eurof } \\
\text { Indicators }\end{array}$ & DK & \multicolumn{2}{|c|}{ EE } & FI & IS & \multicolumn{2}{|c|}{$\mathbf{L V}$} & LT & \multicolumn{2}{|c|}{ NO } & UK & \multicolumn{2}{|c|}{ IE } & SE \\
\hline $\begin{array}{c}\text { Business } \\
\text { climate }\end{array}$ & A1 & \multicolumn{2}{|c|}{ A2 } & A1 & A1 & \multicolumn{2}{|c|}{ A3 } & A2 & \multicolumn{2}{|c|}{ A1 } & A1 & \multicolumn{2}{|c|}{ A1 } & A1 \\
\hline $\begin{array}{c}\text { Country } \\
\text { risk }\end{array}$ & A3 & \multicolumn{2}{|c|}{ A3 } & A2 & A3 & \multicolumn{2}{|c|}{ B } & A4 & \multicolumn{2}{|c|}{ A1 } & A2 & \multicolumn{2}{|c|}{ A3 } & A1 \\
\hline $\begin{array}{c}\text { South } \\
\text { Europe } \\
\text { and } \\
\text { Turky/ } \\
\text { Indicators }\end{array}$ & AL & BA & CY & HR & EL & IT & MK & MT & ME & PT & RS & SI & ES & TR \\
\hline $\begin{array}{l}\text { Business } \\
\text { climate }\end{array}$ & $\mathrm{C}$ & $\mathrm{C}$ & A3 & A3 & A3 & A2 & B & A2 & $\mathrm{C}$ & A2 & $\mathrm{C}$ & A2 & A1 & A4 \\
\hline $\begin{array}{c}\text { Country } \\
\text { risk }\end{array}$ & $\mathrm{C}$ & $\mathrm{D}$ & $\mathrm{C}$ & C & C & B & C & A2 & C & B & C & A4 & A4 & B \\
\hline $\begin{array}{c}\text { West } \\
\text { Europe/ } \\
\text { Indicators }\end{array}$ & $\mathbf{A}^{\prime}$ & & & $\mathbf{E}$ & C & & F & & DF & & $\mathbf{L}$ & & & JL \\
\hline $\begin{array}{c}\text { Business } \\
\text { climate }\end{array}$ & A & & & 1 & A & & A & & A1 & & $A$ & & & $\mathrm{~A} 1$ \\
\hline $\begin{array}{c}\text { Country } \\
\text { risk }\end{array}$ & A & & & 3 & A & & A & & A1 & & $A$ & & & 43 \\
\hline
\end{tabular}

(Source: www.coface.com)

Regarding the performances as well as some problems facing the Northern Europe, business climate is appreciated, in the year 2014, as favorable business development, all the 10 countries of the region satisfying standards of group A; only Latvia is evaluated with the index A3, Lithuania and Estonia - A2 and other countries A1. It is very important proper application and continues to specific mechanisms of the market economy, macroeconomic policies consistent for the improvement of the business environment. On the other hand, country risk perception reflects more rigor quality economic environment and political environment in the countries analyzed, highlighting indices may weaken than those relating to the assessment of the business climate in 8 of the 10 countries of the region; only Norway and Sweden are valued with $\mathrm{A} 1$ on both the indicators.

By analysing quality of the business environment and the country risk of the countries of South-Eastern Europe and Transcontinental, at the level of 2014, the situation is as follows: of the 14 countries in the region, only Spain has earned A1 for business climate, the other member countries of EU receiving evaluation A2 or A3; between non-member countries EU, Turkey has an A4 and the other countries do not meet the conditions to be rewarded with group A. Regarding to the country risk, the assessment is more rigorous, so only Malta, Slovenia and Spain benefit from evaluation in group A, the other 11 countries in the region showing a level of country risk, so the economic, social and political components considered risky enough or even very risky (the case of Bosnia and Herzegovina, group D) to conduct international business, with performance.

Expression of economic, social, political factors of national environments, in correlation with environment variables European and international business, the indicators relating to the assessment of the business climate and the country risk, highlights, for the countries of Western Europe, the most favorable conditions for the conduct of business, sustainable human development. Both the indicators reflect optimal situations from the point of view of the business climate as well as the lowest levels of the country risk in Austria, Switzerland, Germany.

To highlight the impact of the business environment variables on its development, we have calculated the correlations (for year 2012) between: the rate of increase number of enterprises and rate of economic growth; the rate of increase number of enterprises 
and the annual rate of inflation. I have used statistical correlation coefficient, respectively:

$$
\frac{n \sum x y-\sum x \sum y}{\sqrt{\left[n \sum x^{2}-\left(\sum x\right)^{2}\right]\left[n \sum y^{2}-\left(\sum y\right)^{2}\right]}}
$$

Table 2. Some characteristic of business climate in Europe, 2011, 2012

\begin{tabular}{|l|r|r|r|r|r|c|}
\hline \multirow{2}{*}{ Country } & \multicolumn{3}{|c|}{$\mathbf{2 0 1 1}$} & \multicolumn{3}{|c|}{$\mathbf{2 0 1 2}$} \\
\cline { 2 - 7 } & $\begin{array}{c}\text { Number of } \\
\text { enterprises }\end{array}$ & $\begin{array}{c}\text { GDP } \\
\text { growth } \\
\mathbf{( \% )}\end{array}$ & $\begin{array}{c}\text { Inflation } \\
\mathbf{( \% )}\end{array}$ & $\begin{array}{c}\text { Number of } \\
\text { enterprises }\end{array}$ & $\begin{array}{c}\text { GDP } \\
\text { growth } \\
(\%)\end{array}$ & $\begin{array}{c}\text { Inflation } \\
\mathbf{( \% )}\end{array}$ \\
\hline Belgium & 550.777 & 1,8 & 3,4 & 566.006 & $-0,1$ & 2,6 \\
\hline Bulgaria & 309.953 & 1,8 & 3,4 & 312.608 & 0,8 & 2,4 \\
\hline Estonia & 54.933 & 9,6 & 5,1 & 58.408 & 3,9 & 4,2 \\
\hline Spain & 2.087 .372 & 0,1 & 3,1 & 2.385 .077 & $-1,6$ & 2,4 \\
\hline Croatia & 153.687 & $-0,2$ & 2,3 & 148.573 & $-1,9$ & 3,4 \\
\hline Latvia & 79.234 & 5,5 & 4,2 & 91.939 & 5,6 & 2,3 \\
\hline Lithuania & 127.517 & 5,9 & 4,1 & 141.893 & 3,6 & 3,2 \\
\hline Luxembourg & 29.165 & 1,9 & 3,7 & 29.265 & $-0,2$ & 2,9 \\
\hline Hungary & 550.259 & 1,6 & 3,9 & 528.519 & $-1,7$ & 5,7 \\
\hline Malta & 27.664 & 1,8 & 2,5 & 26.796 & 1 & 3,2 \\
\hline Austria & 304.242 & 2,8 & 3,6 & 308.411 & 0,9 & 2,6 \\
\hline Poland & 1.523 .418 & 1,9 & 3,7 & 1.519 .904 & 1,6 & 0,9 \\
\hline Portugal & 831.655 & $-1,3$ & 3,6 & 793.235 & $-3,2$ & 2,8 \\
\hline Romania & 408.951 & 2,2 & 5,8 & 425.731 & 0,7 & 3,4 \\
\hline Slovenia & 117.481 & 1 & 2,1 & 119.644 & $-2,5$ & 2,8 \\
\hline Slovakia & 414.905 & 3,2 & 4,1 & 398.392 & 2 & 3,7 \\
\hline Sweden & 651.418 & 2,9 & 3 & 661.822 & 1,3 & 1 \\
\hline United Kingdom & 1.696 .589 & 1,1 & 4,5 & 1.703 .562 & 0,3 & 2,8 \\
\hline Norway & 272.264 & 1,3 & 1,3 & 278.899 & 3 & 0,7 \\
\hline
\end{tabular}

(Source: http://ec.europa.eu/eurostat/statistics; www.coface.com)

Statistical correlation coefficient between the rate of increase in the number of enterprises and the economic growth rate, $\mathrm{r}_{1}=0,511664$ so, between those two indicators there is a direct connection, of medium intensity, which confirms the interrelationship among the national economic system and the role of positive economic growth in economic development in the future; moreover, the relationship between the economic growth and dynamics of enterprises is two-way.

Statistical correlation coefficient between the rate of increase in the number of enterprises and the rate of inflation, $r_{2}=-0,35693$ so, between the two indicators there is a reverse link, of low intensity, reflecting the favourable situation of the economy of European countries considered that moderate inflation rates, stimulating business environment and entrepreneurship development.

\section{Conclusions}

Analyzing the evolution of the GDP growth in the continent as a whole, we note that, after the years 2012, 2013, years of economic recession, 2014 marks the invigoration of economic development. Inflation is generally „quiet” or moderate but, in countries such as Belarus, Turkey, Ukraine, Russian Federation, Republic of Moldova, high levels of inflation rate, in the year 2014, may discourage business initiatives. High budget deficit in 2012 and 2013, in several European countries, has the tendency to decline in 2014, with the exception of: Albania, Cyprus, Serbia. In the statement of deficit of the current account shall be placed, in 2014, the non-member countries of the EU (Montenegro, Moldova, Belarus, Albania, Bosnia and Herzegovina, Ukraine, 
Turkey) in which, as in the case of the budget deficit, the motives are not, mainly of an economic nature but correlated, political, social, economic. In the situation of high public debt, in the year 2014, was developed countries, in the EU or outside reflecting its perpetuation of effects from contemporary economic and financial crisis (Greece, Portugal, Spain, Cyprus, etc.). Knowledge of the business climate, the country risk is important because achieving enterprise on the external markets is also determined by the conditions of access and their development in various countries (Prunea, P.).

Recent developments on the European continent shows beyond the credible, reasoned image of developed countries, propagated in business environment, attention must be directed toward the whole societal system in Europe, both from the economic point of view as well as socio-political.

\section{References}

Danu, M.C. (2013), Mediul de afaceri european, Editura Alma Mater, Bacău.

Datasets available at http://epp.eurostat.ec.europa.eu/.

Datasets available at www.coface.com/.

Datasets available at www.un.org/.

Prunea, P. (2003), Riscul în activitatea economică, Editura Economică, București. 